\title{
Fuzzy Linear Programming Dalam Optimalisasi Pelayanan Air Bersih Perusahaan Daerah Air Minum (PDAM) Kab. Jeneponto Menggunakan Metode Sabiha
}

\author{
Wahidah Sanusi ${ }^{1, a)}$, dan Sukarna ${ }^{1, b)}, \&$ Irham Aryandi Basir ${ }^{1, c)}$ \\ ${ }^{1}$ Jurusan Matematika FMIPA Universitas Negeri Makassar, 90224 \\ a)wahidah.sanusi@unm.ac.id \\ b) sukarna@unm.ac.id \\ c)irham.basir@live.com
}

\begin{abstract}
Abstrak. Fuzzy linear programing merupakan pengembangan model program linear dalam menentukan nilai optimal yang mengandung bilangan fuzzy. Metode yang dapat digunakan dalam menyelesaikan fuzzy linear programing yaitu metode Sabiha. Penggunaan metode Sabiha didasarkan pada bilangan linear fuzzy real yang berbentuk bilangan triplet. Pada penelitian ini digunakan model Fuzzy linear programing dalam menentukan nilai optimal pelayanan PDAM Kab. Jeneponto dengan metode sabiha. Menyusun setiap indikator fungsi tujuan $(Z)$ dan fungsi kendala untuk dioptimalkan.. Hasil penyelesaian model diperoleh nilai optimal total pelanggan 9075,999999999990. Untuk setiap variabel tujuan dengan nilai optimal 8896, 999999999990 untuk jenis pelanggan rumah tangga, 96,0000000000112 untuk jenis pelanggan sosial khusus, dan 82,9999999999982 untuk jenis pelanggan sosial umum. Dengan total pendapatan optimal Rp. 4.753.125.000 dan total permintaan air $1.082 .303 \mathrm{~m}^{3}$.

Kata Kunci : Program Linear, Fuzzy Linear Programing, Linear Fuzzy Number. Metode Sabiha, Optimalisasi.
\end{abstract}

\begin{abstract}
Linear fuzzy programing is advance model for linear programing to determin the optimal result that contains fuzzy numbers. Linear Fuzzy programing can be solved using Sabiha's method. Which is based on real linear fuzzy numbers in triplet numbers form. This paper used linear fuzzy programming model and Sabiha's method, to determin the optimal solution on PDAM Kab. Jeneponto's operation plan. Each indicator constructed to optimized objective function and constraint function. Results of this research have optimal solution for each objective variable was obtained with an optimal value for total costumer are 9075,999999999990 from 8896,999999999990 the type of household customer, 96,0000000000112 the type of special social customer, and 82,99999999999982 the type of public social costumer. With an optimal total revenue Rp. 4,753,125,000 and total water demand 1,082,303 $\mathrm{m}^{3}$.

Keywords: Linear Programing, Linear Fuzzy Programing, Linear Fuzzy Number, Sabiha's Method, Optimalization.
\end{abstract}

\section{PENDAHULUAN}

Program Linear (PL) merupakan pemodelan matematika dalam pengambilan keputusan dengan mengoptimalkan sumber daya yang ada. Untuk mendapatkan hasil PL tersebut, setiap sumber daya diubah kedalam bentuk abstrak atau simbol matematika yang mendekati keadaan sebenarnya 
(Eky, Irwanto \& Ratnasari, 2016). Penggunaan PL dalam optimalisasi hanya terbatas pada data yang pasti/jelas. Sehingga digunakan konsep himpunan samar (fuzzy) dalam pemodelan PL.

Konsep himpunan samar merupakan himpunan yang memiliki batas keanggotaan tidak pasti. Keanggotaan himpunan samar dinyatakan dalam derajat keanggotaan (George \& Yuan, 1995). Penggunaan konsep himpunan samar dalam cabang ilmu matematika muncul secara eksplisit dan implisit sebagai konsep dasar. Pada kasus pengambilan keputusan himpunan samar digunakan pada model PL yang disebut sebagai Fuzzy Linear Programing (FLP) (Abdy, 2008).

FLP merupakan penggabungan antara konsep himpunan samar dan PL dalam pengambilan keputusan dengan koefisien yang tidak berbentuk probabilistik atau fungsi kendala yang tidak pasti (Abdullah \& Abidin, 2014). FLP juga diartikan sebagai model yang digunakan untuk mencari solusi optimum fungsi objektif $(\mathrm{Z})$ dengan mengoptimalkan fungsi kendala yang berbentuk himpunan samar (Kusumadewi \& Purnomo, 2010). Penggunaan FLP dalam pengambilan keputusan didasarkan terhadap masalah-masalah linier yang memiliki keterkaitan dengan PL yang bersifat samar (Sabiha \& Zaki. 2010).

Beberapa penelitian telah menggunakan model FLP (Abdullah \& Abididn, 2014; Nurul \& Gusti, 2013; Eky, dkk, 2016). Abdullah \& Abidin (2014) mengunakan model FLP dalam menentukan nilai optimal produksi daging pada senbuah pabrik. Nurul \& Gusti (2014) menggunakan Fuzzy goal programing dalam menentukan nilai optimal pelanggan pada PDAM Kota Surabaya. Adapun penelitian Eky, dkk (2016) yaitu mencari solusi dari sebuah FLP dengan bilangan Fuzzy Linear Real (LFR) menggunakan metode sabiha.

Metode Sabiha merupakan hasil modifikasi menggunakan teknik dua fase dengan mengubah bentuk umum matriks triplet menjadi tiga matriks single (tunggal). Dilakukan sebelum iterasi fase pertama sampai akhir dari iterasi fase kedua (Eky, dkk, 2016). Dalam kehidupan nyata metode sabiha ini lebih mendekati pada situasi nilai optimum crisp tidak diketahui secara jelas, tetapi memiliki hasil yang optimum (Sabiha \& Zaki, 2010).

Penelitian ini menggunakan model FLP dan metode Sabiha dalam menentukan nilai optimum dari fungsi objektif $(Z)$. Kasus yang diangkat pada penelitian ini menentukan jumlah pelanggan optimal pada PDAM Kab. Jeneponto.

\section{TINJAUAN PUSTAKA}

\section{Teori Himpunan Samar}

Definisi 1 (Rogers \& Yuan, 1995)

Jika terdapat himpunan A dalam himpunan Semesta $U$ yang didefinisikan sebagai himpunan samar maka fungsi keanggotaan $\mu_{A}(x)$ untuk setiap $x \in U$ bilangan real, adalah nilai dalam interval $[0,1], \mu_{A}(x) \rightarrow[0,1]$, untuk $\mu_{A}(x)$ menyatakan derajat keanggotaan $x$ di dalam A.

\section{Linear Fuzzy Real Number (LFR)}

Definisi 2 (Rogers \& Jun, 2008)

Bilangan samar riil atau $L F R$ didefinisikan sebagai triple bilangan real $(a, b, c)$ dimana $a \leq b \leq c$.

a) $\mu(x)=1$ jika $x=b$

b) $\mu(x)=0$ jika $x \leq$ atau $\geq c$

c) $\mu(x)=\frac{x-a}{b-a}$ jika $a<x<b$

d) $\mu(x)=\frac{c-x}{c-b}$ jika $b<x<c$ 
Diasumsikan bahwa terdapat data bersifat triple bilangan rill $(a, b, c)$ dengan $a \leq b \leq c$ sesuai Definisi 2. diartikan sebagai bilangan $L F R=\mu=\mu(a, b, c)$ yang diilustrasikan pada Gambar 1 .

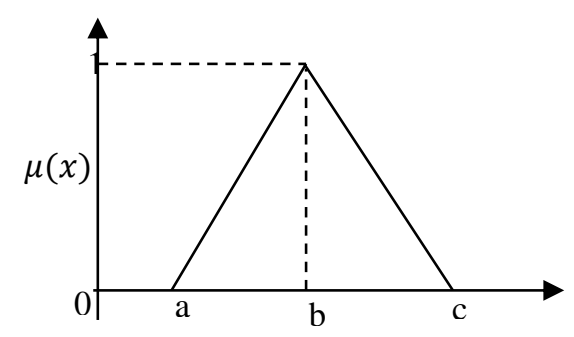

GAMBAR 1. Bilangan $L F R$

\section{Operasi Bilangan $L F R$}

Berikut beberapa syarat operasi perhitungan pada bilangan $L F R$.

\section{Penjumlahan}

Jika terdapat bilangan $L F R \quad \mu_{1}=\left(a_{1}, b_{1}, c_{1}\right)$ dan $\mu_{2}=\left(a_{2}, b_{2}, c_{2}\right)$, maka

$$
\mu_{1}+\mu_{2}=\left(a_{1}+a_{2}, b_{1}+b_{2}, c_{1}+c_{2}\right)
$$

\section{Pengurangan}

Untuk operasi pengurangan adalah sebagai berikut

$$
\begin{array}{r}
\mu_{1}=\left(a_{1}, b_{1}, c_{1}\right) \text { dan } \mu_{2}=\left(a_{2}, b_{2}, c_{2}\right) . \text { Jika }-\mu_{2}(a, b, c)=\mu_{2}(-c,-b,-a) \mathrm{d} \\
\mu_{1}+\mu_{2}=\left(a_{1}-a_{2}, b_{1}-b_{2}, c_{1}-c_{2}\right)
\end{array}
$$

\section{Perkalian}

Diberikan bilangan $L F R$ yaitu $\mu_{1}=\left(a_{1}, b_{1}, c_{1}\right)$ dan $\mu_{2}=\mu\left(a_{2}, b_{2}, c_{2}\right)$, maka

$$
\mu_{1} \cdot \mu_{2}=\left(\min \left\{a_{1} a_{2}, a_{1} c_{2}, a_{2} c_{1}, c_{1} c_{2}\right\}, b_{1} b_{2}, \max \left\{a_{1} a_{2}, a_{1} c_{2}, a_{2} c_{1}, c_{1} c_{2}\right\}\right)
$$

Jadi jika $\mu_{i}=\left(a_{i}, b_{i}, c_{i}\right)$ untuk $i=1,2,3$, maka

$$
\mu_{1} \cdot \mu_{2} \cdot \mu_{3}=\left(\min \left\{a_{1} a_{2} a_{3}, \ldots, c_{1} c_{2} c_{3}\right\}, b_{1} b_{2} b_{3}, \max \left\{a_{1} a_{2} a_{3}, \ldots, c_{1} c_{2} c_{3}\right\}\right)
$$

Dengan demikian berlaku $\mu \cdot(1)=\mu$ untuk setiap $\mu \in L F R$.

\section{Pembagian}

Diberikan bilangan $L F R$ yaitu $\mu_{1}=\left(a_{1}, b_{1}, c_{1}\right)$ dan $\mu_{2}=\mu\left(a_{2}, b_{2}, c_{2}\right)$, maka

$$
\frac{\mu_{1}}{\mu_{2}}=\mu_{1} \cdot \frac{1}{\mu_{2}}
$$

Dimana,

$\frac{1}{\mu_{2}}=\mu\left(\min \left(\frac{1}{a_{2}}, \frac{1}{b_{2}}, \frac{1}{c_{2}}\right)\right.$, median $\left.\left(\frac{1}{a_{2}}, \frac{1}{b_{2}}, \frac{1}{c_{2}}\right), \max \left(\frac{1}{a_{2}}, \frac{1}{b_{2}}, \frac{1}{c_{2}}\right)\right)$

Dengan demikian untuk $(a, b, c)$, jika $0<a \leq b \leq c$ maka

$$
\frac{1}{\mu}=\mu\left(\frac{1}{c}, \frac{1}{b}, \frac{1}{a}\right)
$$

\section{Bentuk Umum FLP}

Model FLP memiliki tiga unsur utama yaitu variabel keputusan, fungsi objektif, kendala utama. Bentuk umum model FLP (Kumar, 2010). 
Fungsi tujuan

$$
\max \left(\text { or minimum) } \sum_{j=1}^{n} \mu C_{j} X_{j}\right.
$$

Dengan fungsi kendala:

$$
\sum_{j=1}^{n} \mu A_{i j} X_{j} \leq,=, \geq \mu B_{i} \quad X_{1} X_{2}, \ldots, X_{n} \geq 0
$$

Dimana,

$X_{j}$ : Variabel keputusan

$C_{j}$ : Koefisien biaya

$B_{i}$ : Suku tetap kendala utama

$A_{i j}$ : Koefisien fungsi kendala

\section{Metode Sabiha}

Metode Sabiha terdiri dari dua fase.

\section{Fase pertama}

a. Mengubah rincian teknis dari permasalahan PL ke dalam bentuk pertidaksamaan fuzzy dan menjadikannya sebagai pernyataan sehingga dapat diperoleh fungsi objektif dan kendala dalam bentuk fuzzy.

b. Mengubah setiap kendala sedemikian sehingga ruas kanan pada setiap kendala berharga non negatif. Langkah ini mengharuskan setiap kendala dengan ruas kanan yang bernilai negatif dikalikan dengan -1 .

c. Mengubah setiap pertidaksamaan kendala ke dalam bentuk baku, yaitu jika kendala $i$ berbentuk $\leq$ maka ditambahkan variabel slack/kelonggaran $(s i)$ pada ruas kiri. Jika kendala $i$ berbentuk $\geq$ maka dikurangi variabel excess (ei) atau variabel surplus (si) pada ruas kiri.

d. Menambahkan variabel artificial (semu) yang diperlukan dari tipe masalah dengan kendala "=" atau " $\geq$ " untuk memperoleh penyelesaian basis fisibel awal.

e. Membentuk fungsi objektif baru dengan meminimumkan penjumlahan variabel semu terhadap kendala semula yang sudah dibawa ke bentuk baku dan sudah ditambah variabel semu.

$R=$ penjumlahan dari semua variabel semu

$$
R=\sum_{i=1}^{j} R_{i}
$$

f. Memodifikasikan bentuk umum untuk disesuaikan dengan "matriks triplet", sedemikian sehingga satu matriks dari matriks triplet dipecah menjadi tiga matriks single (tunggal). Oleh karena itu kita pisahkan $(\mu i j)=(A, B, C)$, dimana $A=(a i j), B=(b i j), \operatorname{dan} C=(c i j)$.

g. Mencari penyelesaian basis fisibel awal dari persamaan dengan langkah iterasi [1]. Langkah iterasi memiliki tiga bagian:

1) Menentukan Entering Variable (EV), yaitu variabel yang masuk menjadi basis dengan cara mencari variabel non basis pada persamaan yang memiliki harga negatif terbesar untuk masalah maksimum dan harga positif terbesar untuk masalah minimum.

2) Menentukan Leaving Variable ( $L V)$, yaitu variabel basis yang akan keluar dengan cara membandingkan harga ruas kanan $(\mu b i)$ dengan harga koefisien 
pada variabel yang terpilih menjadi basis baru pada setiap persamaan ke- $i$ ( $i$ $=1,2, \ldots, j)$, yang dipilih adalah yang paling minimum. Selanjutnya perpotongan antara $E V$ dan $L V$ dapat disebut sebagai elemen pivot.

3) Menentukan solusi baru dengan melakukan operasi eliminasi Gauss, dengan menjadikan setiap harga pada variabel baru menjadi nol dan elemen pivot menjadi 1.

Jika nilai optimal dari fungsi objektif tersebut positif $(R>0)$ maka PLF mempunyai solusi yang tidak fisibel sehingga mengakhiri proses

h. Jika nilai optimal dari fungsi objektif tersebut sama dengan nol $(R=0)$ maka PLF mempunyai solusi fisibel sehingga dapat dilanjutkan ke fase kedua.

\section{Fase Kedua}

Menggunakan solusi fisibel dari fase I yaitu penyelesaian fisibel awal (menjadi tabel awal) untuk permasalahan awal yang sesungguhnya dengan mensubstitusikan persamaan yang diperoleh dari fase I ke dalam persamaan fungsi tujuan awal sehingga diperoleh persamaan fungsi tujuan baru dengan kendalanya adalah persamaan yang diperoleh dari fase I lalu dilakukan iterasi untuk mendapatkan solusi optimal.

\section{METODE PENELITIAN}

Penelitian ini merupakan penelitian terapan dengan menggunakan model FLP. Tujuan penelitian ini mengetahui model FLP dalam menentukan nilai optimal pelayanan air bersih PDAM Jeneponto Data yang digunakan adalah data jumlah pelanggan, data jumlah permintaan air dan data jumlah pendapatan perencanaan pelayanan PDAM Jeneponto tahun 2017. Variabel keputusan yang digunakan adalah jenis pelanggan Rumah Tangga $\left(\mathrm{X}_{1}\right)$, Sosial Umum $\left(\mathrm{X}_{2}\right)$ dan Sosial Khusus $\left(\mathrm{X}_{3}\right)$.

Metode yang digunakan yaitu metode Sabiha yang terdiri dari dua fase. Fase pertama yaitu membentuk model FLP, mengubah FLP kedalam bentuk baku, menentukan fungsi tujuan semu, membentuk tabel simpleks setiap fungsi kedala FLP dengan fungsi tujuan semua. Fase kedua yaitu menjadikan solusi pada tabel simpleks akhir fase pertama, sebagai tabel simpleks awal pada fase kedua dengan menggunakan fungsi tujuan awal.

\section{HASIL DAN PEMBAHASAN}

\section{Data Penelitian}

Data jumlah pelanggan, jumlah permintaan air, dan jumlah pendapatan penjualan air bersih untuk kurun waktu Januari hingga Desember 2017 dari empat wilayah operasional PDAM Kab. Jeneponto yang dapat dilihat pada Tabel 1.

TABEL 1. Data Permintaan, Pendapatam dan Jumlah Pelanggan tahun 2017

\begin{tabular}{|c|c|c|c|}
\hline Jenis Pelanggan & Permintaan Air & Pendapatan & Jumlah Pelanggan \\
\hline $\mathrm{X}_{1}$ & 1048582 & 4651970375 & 8897 \\
\hline$X_{2}$ & 13152 & 46515625 & 96 \\
\hline$X_{3}$ & 20569 & 54639000 & 83 \\
\hline Total & 1082303 & 4753125000 & 9076 \\
\hline
\end{tabular}

Sumber: PDAM Kab. Jeneponto 
Tabel 1 merupakan data yang digunakan sebagai acuan dalam menentukan koefesien dari FLP. Digunakan juga sebagai acuan dalam menentuka nilai maksumum dan minimum yang dapat diliha pada Tabel 2.

TABEL 2. Nilai Minimum dan Maksimum Permintaan Air, Pendapatan dan Jumlah Pelanggan Setiap Variabel

\begin{tabular}{ccc}
\hline $\begin{array}{c}\text { Jenis } \\
\text { Pelanggan }\end{array}$ & \multicolumn{2}{c}{ Permintaan Air } \\
$\mathrm{X}_{1}$ & 769368 & 1182924 \\
$\mathrm{X}_{2}$ & 10500 & 15072 \\
$\mathrm{X}_{3}$ & 15336 & 22944 \\
\hline Total & $\mathbf{7 9 5 2 0 4}$ & $\mathbf{1 2 2 0 9 4 0}$ \\
\hline Jenis & \multicolumn{2}{c}{ Pendapatan } \\
Pelanggan & Minimum & Maksimum \\
\hline $\mathrm{X}_{1}$ & 3428178000 & 5321121000 \\
$\mathrm{X}_{2}$ & 35119500 & 54912000 \\
$\mathrm{X}_{3}$ & 41745600 & 60933600 \\
\hline Total & $\mathbf{7 9 5 2 0 4}$ & $\mathbf{1 2 2 0 9 4 0}$ \\
\hline Jenis & Jumlah & Pelanggan \\
Pelanggan & Minimum & Maksimum \\
\hline $\mathrm{X}_{1}$ & 8897 & 8897 \\
$\mathrm{X}_{2}$ & 96 & 96 \\
$\mathrm{X}_{3}$ & 83 & 83 \\
\hline Total & $\mathbf{9 0 7 6}$ & $\mathbf{9 0 7 6}$ \\
\hline
\end{tabular}

Nilai minimum dan maksimum pada Tabel 2 digunakan untuk menentukan batas bawah dan batas atas sesuai dengan definisi 2. Selanjutnya digunakan sebagai koefisien dari FLP

\section{Koefisien FLP}

Berdasarkan nilai minimum dan maksimum pada Tabel 2 dan memperhatikan Definisi 2 maka diperoleh koefisien FLP sesuai dengan Tabel 3.

TABEL 3. Koefesien Fungsi Kendala FLP

\begin{tabular}{cccc}
\hline \multicolumn{5}{c}{ Permintaan Air } \\
\hline $\mathbf{X}_{\boldsymbol{j}}$ & $\mathbf{A}$ & $\mathbf{B}$ & $\mathbf{C}$ \\
\hline $\mathrm{X}_{1}$ & 86,4750 & 117,8579 & 132,9576 \\
$\mathrm{X}_{2}$ & 109,3750 & 137 & 157 \\
$\mathbf{X}_{3}$ & 184,7711 & 247,8193 & 276,4337 \\
\hline \multicolumn{4}{c}{ Penjualan Air } \\
\hline $\mathbf{X}_{\boldsymbol{j}}$ & $\mathbf{A}$ & $\mathbf{B}$ & $\mathbf{C}$ \\
\hline $\mathrm{X}_{1}$ & 385318,4219 & 522869,5487 & 598080,3642 \\
$\mathrm{X}_{2}$ & 365828,1250 & 484537,7604 & 572000 \\
$\mathrm{X}_{3}$ & 502959,0361 & 658301,2048 & 734139,7590 \\
\hline \multicolumn{5}{c}{ Jumlah Pelanggan } \\
\hline $\mathbf{X}_{\boldsymbol{j}}$ & $\mathbf{A}$ & $\mathbf{B}$ & $\mathbf{C}$ \\
\hline $\mathrm{X}_{1}$ & 1 & 1 & 1 \\
$\mathrm{X}_{2}$ & 1 & 1 & 1 \\
$\mathrm{X}_{3}$ & 1 & 1 & 1 \\
\hline \multicolumn{5}{c}{}
\end{tabular}


Tabel 3 merupakan koefisen-koefisien yang digunakan dalam model FLP yang telah terbagi kedalam tiga bilangan tirplet A, B, dan C. Ketiga bilangan triplet ini diperoleh dengan membagi setiap indikator variabel pada Tabel 1 dan Tabel 2 terhadap nilai jumlah pelanggan. Proses selanjutnya mengukuti langkah-langkah prosedur dari optimalisasi FLP menggunakan metode Sabiha.

\section{Prosedur Optimalisasi FLP Menggunakan Metode Sabiha}

Membentuk model FLP dengan menggunakan koefisien pada Tabel 3 sehingga diperoleh fungsi objektif/tujuan dengan mengusahakan semaksimal mungkin jumlah pelanggan untuk setiap variabel keputusan

Fungsi tujuan

$$
\text { Maksimum : } Z=\mu X_{1}+\mu X_{2}+\mu X_{3}
$$

Dengan Fungsi kendala

$\mu(86.4750,117.8679,132.9576) \mathrm{X}_{1}+\mu(109.3750,137,157) \mathrm{X}_{2}+$

$\mu(184.7711,247.8193,276.4337) X_{3}=\mu(795204,1082303,1220940)$

$(385318.4219,522869.5487,598080,3642) \mathrm{X}_{1}+\mu(365828.1250,484537,7604,572000) \mathrm{X}_{2}+$ $\mu(502959.0361,658301.2048,734139.7590) X_{3}=\mu(350543100,4753125000,5436966600)$

$\mu(1,1,1) X_{1}+\mu(1,1,1) X_{2}+\mu(1,1,1) X_{3}=\mu(9076,9076,9076)$

Model umum FLP selanjutnya akan dibentuk kedalam model FLP baku dengan menambahkan variabel Semu untuk setiap fungsi kendala.

\section{Bentuk Baku FLP}

Berdasarkan bentuk umum FLP yang telah dibuat maka setiap fungsi kendala diubah ke dalam bentuk baku, yaitu jika kendala berbentuk $\leq$ maka ditambahkan variable slack (si) pada ruas kiri. Jika kendala berbentuk $\geq$ maka dikurangi variabel excess (ei) atau variabel surplus (si) pada ruas kiri, serta Menambahkan variabel artificial (semu) $\left(\mathrm{R}_{\mathrm{i}}\right)$ yang diperlukan dari tipe masalah dengan kendala "=" atau " $\geq$ " untuk memperoleh penyelesaian basis.

$\mu(86.4750,117.8679,132.9576) \mathrm{X}_{1}+\mu(109.3750,137,157) \mathrm{X}_{2}+$

$\mu(184.7711,247.8193,276.4337) \mathrm{X}_{3}+\mathrm{R}_{1}=\mu(795204,1082303,1220940)$

$(385318.4219,522869.5487,598080,3642) \mathrm{X}_{1}+\mu(365828.1250,484537,7604,572000) \mathrm{X}_{2}$ $+\mu(502959.0361,658301.2048,734139.7590) \mathrm{X}_{3}+\mathrm{R}_{2}=\mu(350543100,4753125000,5436966600)$

$\mu(1,1,1) X_{1}+\mu(1,1,1) X_{2}+\mu(1,1,1) X_{3}+R_{3}=\mu(9076,9076,9076)$

\section{Membentuk Fungsi Tujuan Semu (R)}

Membentuk fungsi objektif/tujuan baru dengan memaksimalkan penjumlahan variabel semu terhadap kendala semula yang sudah dibawa ke bentuk baku dan sudah ditambah variabel semu (1). Karena pada penelitian yang dilakukan adalah memaksimalkan pelayanan maka bentuk baru fungsi tujuan dengan melakukan penguranan dari setiap variabel semu.

$$
\begin{gathered}
\mathrm{R}=\sum_{\mathrm{i}=1}^{\mathrm{j}}-\mathrm{R}_{\mathrm{i}} \\
\mathrm{R}=-\mathrm{R}_{1}-\mathrm{R}_{2}-\mathrm{R}_{3}
\end{gathered}
$$


Sehingga, dengan merujuk prinsip operasi penguranga pada bilangan LFR diperoleh:

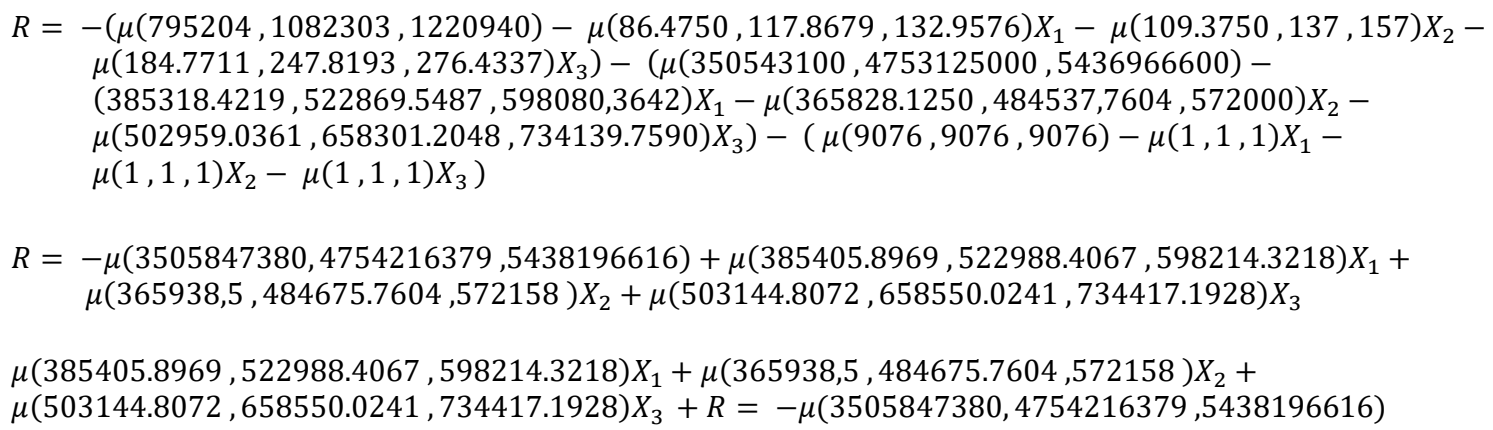

\section{Tabel Simpleks Metode Sabiha}

TABEL 4. Nilai Simpleks awal metode Sabiha Fase I

\begin{tabular}{|c|c|c|c|c|c|c|c|c|}
\hline & & $\mu X_{1}$ & $\mu X_{2}$ & $\mu X_{3}$ & $\mathbf{R}_{1}$ & $\mathbf{R}_{2}$ & $\mathbf{R}_{\mathbf{3}}$ & $\mu \mathbf{B}_{i}$ \\
\hline \multirow{5}{*}{$\mathbf{A}$} & $\mathbf{R}$ & $-385405,8969$ & $-365938,5$ & $-503144,8072$ & 0 & 0 & 0 & -3505847380 \\
\hline & $\mathbf{R}_{1}$ & 86,4750 & 109,3750 & 184,7711 & 1 & 0 & 0 & 795204 \\
\hline & $\mathbf{R}_{2}$ & 385318,4219 & 365828,1250 & 502959,0361 & 0 & 1 & 0 & 3505043100 \\
\hline & $\mathbf{R}_{3}$ & 1 & 1 & 1 & 0 & 0 & 1 & 9076 \\
\hline & & $\mu \mathrm{X}_{1}$ & $\mu \mathrm{X}_{2}$ & $\mu \mathbf{X}_{3}$ & $\mathbf{R}_{1}$ & $\mathbf{R}_{2}$ & $\mathbf{R}_{\mathbf{3}}$ & $\mu \mathbf{B}_{\mathbf{i}}$ \\
\hline \multirow{5}{*}{ B } & $\mathbf{R}$ & $-522988,4067$ & $-484675,7604$ & $-658550,0241$ & 0 & 0 & 0 & -4754216379 \\
\hline & $\mathbf{R}_{1}$ & 117,8579 & 137 & 247,8193 & 1 & 0 & 0 & 1082303 \\
\hline & $\mathbf{R}_{2}$ & 522869,5487 & 484537,7604 & 658301,2048 & 0 & 1 & 0 & 4753125000 \\
\hline & $\mathbf{R}_{3}$ & 1 & 1 & 1 & 0 & 0 & 1 & 9076 \\
\hline & & $\mu \mathrm{X}_{1}$ & $\mu \mathrm{X}_{2}$ & $\mu \mathrm{X}_{3}$ & $\mathbf{R}_{1}$ & $\mathbf{R}_{2}$ & $\mathbf{R}_{3}$ & $\mu \mathbf{B}_{i}$ \\
\hline \multirow{4}{*}{ C } & $\mathbf{R}$ & $-598214,3218$ & -572158 & $-734417,1928$ & 0 & 0 & 0 & -5438196616 \\
\hline & $\mathbf{R}_{1}$ & 132,9576 & 157 & 276,4337 & 1 & 0 & 0 & 1220940 \\
\hline & $\mathbf{R}_{2}$ & 598080,3642 & 572000 & 734139,759 & 0 & 1 & 0 & 5436966600 \\
\hline & $\mathbf{R}_{3}$ & 1 & 1 & 1 & 0 & 0 & 1 & 9076 \\
\hline
\end{tabular}

Tabel 4 merupakan modifikasi bntuk baku FLP kedalam tabel simpleks. Mengubah matriks triplet menjadi tiga matriks single (tunggal) sesuai aturan metode sabiha. Oleh karena itu untuk setiap $(\mu i j)=(A, B, C)$, diubah menjadi $=(a i j), B=(b i j)$, dan $C=(c i j)$

TABEL 5. Tabel Simpleks Iterasi 1 Fase I

\begin{tabular}{|c|c|c|c|c|c|c|c|c|c|}
\hline & & $\mu \mathrm{X} 1$ & $\mu \mathrm{X} 2$ & $\mu \mathrm{X}^{*}$ & R1 & $\mathbf{R 2}$ & $\mathbf{R 3}$ & $\mu \mathbf{B i}$ & Rasio \\
\hline \multirow{4}{*}{$\mathbf{A}$} & $\mathbf{R}$ & -385405.8969 & -365938.5 & -503144.8072 & 0 & 0 & 0 & -3505847380 & 6967,869547 \\
\hline & R1* & 86.4750 & 109.3750 & $184.7711 * *$ & 1 & 0 & 0 & 795204 & 4303,725352 \\
\hline & $\mathbf{R 2}$ & 385318.4219 & 365828.1250 & 502959.0361 & 0 & 1 & 0 & 3505043100 & 6968,844077 \\
\hline & $\mathbf{R 3}$ & 1 & 1 & 1 & 0 & 0 & 1 & 9076 & 9076 \\
\hline & & $\mu \mathrm{X} 1$ & $\mu \mathrm{X} 2$ & $\boldsymbol{\mu} \mathbf{X} 3^{*}$ & R1 & $\mathbf{R 2}$ & $\mathbf{R 3}$ & $\mu \mathbf{B i}$ & Rasio \\
\hline \multirow{5}{*}{ B } & $\mathbf{R}$ & $-522988,4067$ & $-484675,7604$ & $-658550,0241$ & 0 & 0 & 0 & -4754216379 & 6967,869547 \\
\hline & R1* & 117,8579 & 137 & $247,8193 * *$ & 1 & 0 & 0 & 1082303 & 4303,725352 \\
\hline & $\mathbf{R 2}$ & 522869,5487 & 484537,7604 & 658301,2048 & 0 & 1 & 0 & 4753125000 & 6968,844077 \\
\hline & $\mathbf{R 3}$ & 1 & 1 & 1 & 0 & 0 & 1 & 9076 & 9076 \\
\hline & & $\mu \mathrm{X} 1$ & $\mu \mathrm{X} 2$ & $\boldsymbol{\mu} \mathbf{X} 3 *$ & $\mathbf{R 1}$ & $\mathbf{R 2}$ & $\mathbf{R 3}$ & $\mu \mathbf{B i}$ & Rasio \\
\hline \multirow{4}{*}{ C } & $\mathbf{R}$ & $-598214,3218$ & -572158 & $-734417,1928$ & 0 & 0 & 0 & -5438196616 & 7404,778469 \\
\hline & R1* & 132,9576 & 157 & $276,4337 * *$ & 1 & 0 & 0 & 1220940 & 4416,754707 \\
\hline & $\mathbf{R 2}$ & 598080,3642 & 572000 & 734139,759 & 0 & 1 & 0 & 5436966600 & 7405,901306 \\
\hline & $\mathbf{R 3}$ & 1 & 1 & 1 & 0 & 0 & 1 & 9076 & 9076 \\
\hline
\end{tabular}


Tabel 5 yaitu menentukan Entering Variable (EV) dan Leaving Variable (LV) untuk menemukan variabel yang sama yaitu $\mu \mathrm{X}$ 3. LV untuk setiap matriks tunggal $\mathrm{A}, \mathrm{B}$ dan $\mathrm{C}$ berada pada variabel R1. Elemen pivot iterasi pertama berada pada irisan antara EV dan LV.

TABEL 6. Tabel Simpleks Iterasi 3 Fase I

\begin{tabular}{|c|c|c|c|c|c|c|c|c|c|}
\hline & & $\mu \mathrm{X} 1$ & $\mu \mathrm{X} 2$ & $\mu \mathrm{X3}$ & R1 & $\mathbf{R 2}$ & $\mathbf{R 3}$ & $\mu \mathbf{B i}$ & Rasio \\
\hline \multirow{5}{*}{$\mathbf{A}$} & $\mathbf{R}$ & 0 & 0 & 0 & 1 & & 1 & 0,000001193944 & \\
\hline & $\boldsymbol{\mu} \mathrm{X} 3$ & 0 & 0 & 1 & 0,0042 & & $-2,2798$ & 83,000000000012 & \\
\hline & $\mu \mathrm{X} 1$ & 1 & 0 & 0 & $-0,0297$ & & $-2,7297$ & 8897,000000000050 & \\
\hline & $\mu \mathrm{X} 2$ & 0 & 1 & 0 & 0,0255 & & 6,0095 & 95,999999999933 & \\
\hline & & $\mu \mathrm{X} 1$ & $\mu \mathrm{X2}$ & $\mu \mathrm{X3}$ & R1 & $\mathbf{R 2}$ & R3 & $\mu B i$ & Rasio \\
\hline \multirow{5}{*}{ B } & $\mathbf{R}$ & 0 & 0 & 0 & 1 & & 1 & $-0,000000325492$ & \\
\hline & $\mu \mathrm{X} 3$ & 0 & 0 & 1 & 0,0051 & & $-1,9179$ & 82,9999999999982 & \\
\hline & $\boldsymbol{\mu} \mathrm{X} 1$ & 1 & 0 & 0 & $-0,0229$ & & $-3,9464$ & 8896,999999999970 & \\
\hline & $\mu \mathrm{X} 2$ & 0 & 1 & 0 & 0,0179 & & 6,8643 & 96,000000000036 & \\
\hline & & $\mu \mathrm{X1}$ & $\mu \mathrm{X} 2$ & $\mu \mathrm{X3}$ & R1 & $\mathbf{R 2}$ & R3 & $\mu \mathrm{Bi}$ & $\mathrm{R}$ asio \\
\hline \multirow{4}{*}{$\mathbf{C}$} & $\mathbf{R}$ & 0 & 0 & 0 & 1 & & 1 & $-0,000001309438$ & \\
\hline & $\mu \mathrm{X3}$ & 0 & 0 & 1 & 0,0037 & & $-2,5448$ & 82,999999999997 & \\
\hline & $\boldsymbol{\mu} \mathrm{X} \mathbf{1}$ & 1 & 0 & 0 & $-0,0231$ & & $-6,1114$ & 8896,999999999990 & \\
\hline & $\mu \mathrm{X} 2$ & 0 & 1 & 0 & 0,0194 & & 9,6562 & 96,0000000000112 & \\
\hline
\end{tabular}

Solusi pada iterasi ketiga menunjukkan nilai otpimal dari fungsi tujuan sama dengan nol $(R=0)$ untuk setiap matriks tunggal A, B dan C. FLP mempunyai hasil yang visibel dan dapat dilanjutkan pada fase kedua. Nilai optimal pada fase pertama menjadi tabel awal pada fase kedua dengan fungsi objektif yang sebenarnya (Z). Tabel 6 terlihat bahwa keadaan sudah optimal sehingga tidak perlu dilakukan iterasi lagi dan sudah diperoleh nilai berikut:

$$
\begin{array}{rrl}
\mu X_{1}=(8896,999999999970 & 8896,999999999990 & 8897,000000000050) \\
\mu X_{2}=(95,999999999933 & 96,0000000000112 & 96,000000000036) \\
\mu X_{3}=(82,999999999997 & 82,9999999999982 & 83,000000000012)
\end{array}
$$

dengan nilai optimum crisp/pasti berdasarkan bilangan LFR/Z adalah

$$
\begin{gathered}
\mu X_{1} \in(8896,999999999990), \\
\mu X_{2} \in(96,0000000000112), \\
\mu X_{3} \in(82,999999999998),
\end{gathered}
$$

selanjutnya nilai $\mu X_{1}, \mu X_{2}, \mu X_{3}$ disubtitusikan kedalam fungsi tujuan awal $Z$ sehingga diperoleh

$$
Z=\mu(9075,999999999890,9075.9999999999994,9076,000000000100)
$$

dan nilai crisp/pasti berdasarkan LFR/Z $\in$ ( 9075.9999999999994).

TABEL 7. Hasil Perhitungan Pencapaian Jumlah Pelanggan Air Bersih

\begin{tabular}{lllccc}
\hline No & Variabel & Deskripsi & $\begin{array}{c}\text { Jumlah } \\
\text { Pelanggan }\end{array}$ & $\begin{array}{c}\text { Realisasi } \\
\text { Perhitungan }\end{array}$ & $\begin{array}{c}\text { Persentase } \\
\text { Pencapaian (\%) }\end{array}$ \\
\hline 1 & $\mu X_{1}$ & Rumah Tangga & 8897 & 8896,999999999990 & $100,00000000001 \%$ \\
2 & $\mu X_{2}$ & Sosial Khusus & 96 & 96,0000000000112 & $99,9999999999884 \%$ \\
3 & $\mu X_{3}$ & Sosial Umum & 83 & 82,99999999999982 & $100,000000000002 \%$ \\
\hline
\end{tabular}

Tabel 7 menunjukkan seluruh variabel sasaran optimasi pelayanan air bersih tercapai. Secara persentase masih terjadi peningkatan dan penurunan pencapaian terlihat hanya jenis pelanggan Rumah Tangga dan Sosial Khusus yang mencapai nilai $100 \%$. 


\section{KESIMPULAN}

Penelitian menggunakan FLP dalam menentukan nilai optimum perencanaan pelayanan air bersih PDAM Kab. Jeneponto. Data diubah kedalam bentuk fuzzy dengan menggunkan prinsip LFR. Memodelkan setiap data dalam bentuk FLP. Memodifikasi FLP kebentuk Tabel Simpleks. Menentutukan solusi menggunkanan metode Sabiha.

Hasil yang diperoleh dalam pengoptimalan pelayanan PDAM Kab. Jeneponto yaitu $Z=\mu(9075,999999999890,9075.9999999999994,9076,000000000100)$.

Dalam bentuk LFR/Z bernilai 9075.9999999999994. Sehingga untuk mendapatkan pendapatan Rp 4.753.125.000 dari jumlah permintaan air sebesar 1.082.303 $\mathrm{m}^{3}$ PDAM Jeneponto hanya membutuhkan 9075.9999999999994 unit jumlah pelanggan.

\section{DAFTAR PUSTAKA}

Abdullah, L., \& Abidin, H. (2014). A Fuzzy Liniear Programming in Optimizing Meat Production. International Journal of Engineering and Technology, 6.

Abdy, M. (2008). Dasar-Dasar Teori Himpunan Kabur dan Logika Kabur. Makassar: Badan Penerbit UNM

Eky, Irawanto., \& Ratnasari. (2016). Penyelesaian Masalah Program Linier Fuzzy dengan Bilangan Fuzzy Linear Real Menggunakan Metode Sabiha. Jurnal Matematika, (3).

Georg, J. K., \& Yuan, B. (1995). Fuzzy Sets And Fuzzy Logic - Theory and Application. New Jersey: Prectice Hall PTR.

Kumar, A. (2010). Fuzzy Optimal Solution of Fully Fuzzy Linear Problems with Inequality Constraints." International Journal of Applied Mathematics and Computer Sciences 6. 1.

Kusumadewi, S., \& Purnomo, H. (2010). Aplikasi Logika Fuzzy untuk Pendukung Keputusan Edisi 2. Yogyakarta: Graha Ilmu.

Nurul,. \& Gusti. (2013). Optimasi Jumlah Pelanggan Perusahaan Daerah Air Minum Surya Sembada Kota Surabaya Berdasarkan Jenis Pelanggan Dengan Metode Fuzzy Goal Programming. Jurnal Sains dan Seni POMITS. 1(1).

PDAM Kab. Jeneponto. (2017). Data Perencanaan Pelayanan PDAM 2017. Jeneponto: PDAM Kab. Jeneponto

Rogers, F. N., \& Jun, J. Y. (2008). Method for Optimizing Linear Problems with Fuzzy Constraints. International Mathematical Forum. 3(23).

Sabiha, J. F., \& Zaki, S. T.(2010) Proposed Method for Optimizing Fuzzy Linear Programming Problems by Using Two-Phase Technique. Iraq J. Electrical and Electronic Engineering. $6(2)$. 